\title{
Effect of N-Acetyl Cysteine administration to the degree of parasitemia and plasma interleukin-12 level of mice infected with plasmodium berghei and treated with artemisinin
}

\author{
Loeki Enggar Fitri ${ }^{1}$, Hannatur Rosyidah ${ }^{2}$, Nur Permata Sari ${ }^{3}$, Agustina Tri Endarti ${ }^{1}$ \\ ${ }^{1}$ Laboratory of Parasitology, Medical Faculty Brawijaya University, Malang, Indonesia \\ ${ }^{2}$ Biomedical Postgraduate Departement, Brawijaya University, Malang, Indonesia \\ ${ }^{3}$ Laboratory of Pharmacology, Medical Faculty Brawijaya University, Malang, Indonesia
}

\begin{abstract}
Abstrak
Pendahuluan Proteksi terhadap infeksi malaria memerlukan respon imun seluler yang dimulai dengan pelepasan interleukin-12 (IL-12) dari antigen presenting cells (APC). N-Acetyl Cysteine (NAC) imerupakan precursor dari glutathione, sementara glutathione dapat meningkatkan produksi IL-12. Pemberian NAC yang dikombinasi dengan artemisinin diharapkan akan meningkatkan imunitas seluler dari mencit selama infeksi Plasmodium berghei. Tujuan dari penelitian ini adalah untuk mengetahui efek pemberian NAC terhadap derajat parasitemia dan kadar IL-12 plasma pada mencit yang diinfeksi dengan P. berghei dan diterapi dengan artemisinin.

Metode Desain dari penelitian ini adalah post-test-control-only design menggunakan 5 kelompok mencit yang terdiri dari kelompok A (kelompok kontrol negatif), kelompok $B$ (kelompok kontrol positif, atau mencit yang diinfeksi dengan P.berghei tanpa terapi), kelompok C (mencit yang diinfeksi dengan P.berghei dan diterapi dengan artemisinin $0.04 \mathrm{mg} / \mathrm{g}$ BB selama 7 hari), kelompok D (mencit yang diinfeksi dengan P.berghei dan diterapi dengan artemisinin kombinasi dengan NAC $1 \mathrm{mg} / \mathrm{g} B B$ selama 7 hari) dan kelompok E (mencit yang diinfeksi dengan P.berghei dan diterapi dengan artemisinin kombinasi dengan NAC $1 \mathrm{mg} / \mathrm{g} B B$ selama 3 hari dan diturunkan atau tapering menjadi $0,5 \mathrm{mg} / \mathrm{g}$ BB selama 4 hari). Parasitemia diikuti setiap 2 hari dan setelah 6 hari pasca infeksi atau ketika derajat parasitemia mencapai $\pm 10 \%$ terapi dimulai. Pada hari ke 3, 5, dan 7 setelah terapi, mencit dari tiap kelompok diterminasi dan diukur kadar IL-12 plasma (ELISA, Bender Medsystems GmbH, Vienna, cat. BMS6004).
\end{abstract}

Hasil Hasil penelitian menunjukkan bahwa semua mencit yang diterapi baik dengan artemisinin mono-therapy maupun terapi kombinasi artemisinin dan NAC, derajat parasitemia turun secara bermakna $(P=0.000)$. Tidak ada perbedaan yang bermakna $(P>0.05)$ dalam menurunkan derajat parasitemia di antara kelompok kontrol maupun kelompok perlakuan. Kadar IL-12 plasma meningkat secara bermakna pada kelompok yang menerima terapi kombinasi artemisinin dan NAC baik dosis konstan maupun dosis tapering dibandingkan dengan kelompok yang menerima artemisinin mono-therapy $(p<0,05)$. Kadar IL-12p70 plasma pada kelompok kombinasi artemisinin dan $N A C$ dosis tapering lebih tinggi secara bermakna daripada kelompok lainnya pada hari ke 5 dan 7 pasca terapi.

Kesimpulan Kesimpulan dari penelitian ini adalah artemisinin mono-therapy menurunkan derajat parasitemia sama efektifnya dengan kombinasi artemisinin and NAC. Terapi kombinasi artemisinin dan NAC, dosis konstan maupun tapering, lebih meningkatkan kadar IL-12p70 plasma daripada artemisinin mono-therapy. Kadar IL-12p70 plasma tertinggi ditekan pada kelompok yang diterapi kombinasi artemisinin dan NAC dosis tapering pada pengobatan selama 7 hari. (Med J Indones 2009; 18: 5-9)

\footnotetext{
Abstract

Introduction Protection against malaria requires a cell-mediated immune response which is initiated by releasing interleukin-12 (IL-12) from antigen presenting cells (APC). N-Acetyl Cysteine (NAC) is a precursor of glutathione, while glutathione itself increases IL-12 production. Treatment with NAC combined with artemisinin is supposed to increase cellular immunity of mice during Plasmodium berghei infection. The aim of this study was to measure the effects of NAC administration on the degree of parasitemia and plasma IL-12 level in mice infected with P. berghei and treated with artemisinin.

Method The research was done using post-test-control-only design using 5 groups: group A (negative control group), group B (positive control group, or mice infected with P.berghei without therapy), group C ( mice infected by P.berghei and received artemisinin $0.04 \mathrm{mg} / \mathrm{g} \mathrm{BW}$ for 7 days), group D (mice infected with P.berghei and received artemisinin in combination with NAC $1 \mathrm{mg} / \mathrm{g}$ BW for 7 days) and group E (mice infected wirth P.berghei and received artemisinin
} 
in combination with NAC $1 \mathrm{mg} / \mathrm{g}$ BW for 3 days and tapered into $1 / 2 \mathrm{mg} / \mathrm{g} \mathrm{BW}$ for 4 days). Parasitemia was followed up every two days. Approximately six days post infection or when the degree of parasitemia reached $\pm 10 \%$ therapy was begun. On the 3rd, 5th, and 7th days post therapy, mice from each group were terminated and assayed for plasma IL-12 level (ELISA, Bender Medsystems GmbH, Vienna, cat. BMS6004).

Results All mice treated with artemisinin mono-therapy and combined therapy had significantly decreased parasitemia $(\mathrm{P}=0.000)$. There was no significant difference $(\mathrm{P}>0.05)$ in decreasing parasitemia among treatment groups. The plasma IL-12 level increased significantly in both groups that received the combination of artemisinin and NAC constant dose and tapering dose compared with the group that received artemisinin mono-therapy $(p<0,05)$. Plasma IL-12p70 level in the combination of artemisinin and NAC tapering dose therapy group was higher than other groups on the 5 th and 7 th days post therapy.

Conclusion The conclusion of this research is that artemisinin mono-therapy decreased parasitemia effectively as well as the combination therapy of artemisinin and NAC. Artemisinin and NAC therapy, constant and tapering dose, increase plasma IL-12p70 level more than artemisinin mono-therapy does. The highest plasma IL-12p70 level was found in the artemisinin plus NAC tapering dose therapy group with seven days duration of therapy. (Med J Indones 2009; 18: 5-9)

Keywords: N-acetyl Cysteine, Parasitemia, Interleukin-12, Plasmodium berghei

Malaria remains a major public health problem in most tropical countries, including Indonesia. It has been estimated that 300 to 500 million individuals become infected annually and more than one million people die from malaria every year. ${ }^{1}$ Approximately $60 \%$ of Indonesian people inhabit malaria endemic areas, with various levels of endemicity. ${ }^{2}$

Malaria is caused by Plasmodium, an intracellular protozoa with Plasmodium falciparum as the predominant species in humans. Plasmodium berghei (P. berghei), one of the species infecting rodents, has been widely used as a model for malaria research because of its molecular similarity with $P$. falciparum. ${ }^{3}$

Protection against malaria requires a cell-mediated immune response initiated by the release of interleukin12 (IL-12) by monocytes, macrophages, and other cells. ${ }^{4}$ Down regulation of IL-12 was observed in nonimmune African children with severe P. falciparum malaria. $^{5}$

Interleukin-12 (IL-12) is a hetero-dimeric cytokine composed of $35-\mathrm{kD}(\mathrm{p} 35)$ and $40-\mathrm{kD}(\mathrm{p} 40)$ subunits.

The biologically active form of IL-12 is a protein with 70-kD molecular weight (p70). ${ }^{6}$ Blood stage malaria suppresses systemic IL-12 activity because monocytes ingest hemozoin and promote the overproduction of TNF- $\alpha$ and IL-10. ${ }^{7}$

$N$-Acetyl Cysteine (NAC) was estimated to be a potential antimalaria agent because its cysteine proteinase inhibitor can stabilize the erythrocyte membrane. ${ }^{8} \mathrm{NAC}$ is a precursor of glutathione, and glutathione increases the production of IL-12 from antigen presenting cells. ${ }^{9}$
Hydrogen peroxide $\left(\mathrm{H}_{2} \mathrm{O}_{2}\right)$, a major component of reactive oxygen species (ROSs), inhibits induction of IL-12 p70 in murine macrophages. ${ }^{10}$ Another study reported that there was a decrease of free radicals and an increase of macrophage activity in mice infected with $P$. berghei and treated with a combination of chloroquine and NAC. ${ }^{8}$

Artemisinin is the new future of antimalaria drugs. In order to avoid the occurrence of resistance and to reduce adverse effects of free radicals produced by arthemisinin, it is recommended that Artemisinin is used not as a single therapy, but in combination with other anti malaria or supportive drugs.

A study using artemisinin combined with NAC in severe falciparum malaria showed that there was no adverse reaction to NAC and no mortality in severe malaria patients. ${ }^{11}$ Patients treated with NAC showed accelerating normal serum lactate level, but the mechanism of action is still unclear. The aim of this study was to measure the effects of NAC administration to the degree of parasitemia and plasma IL-12 level in mice infected with $P$. berghei and treated with arthemisin.

\section{METHOD}

Mice. All experiments were carried out with procedures authorized by The Ethics Committee of The University of Brawijaya. Female mice strain BALB/c from Pusat Veterinaria Farma Surabaya were used as samples. Mice were housed according to treatment, there were A, B, C, D, and E groups. Normal mice group (A), non therapy of infected mice group (B) artemisinin therapy 
group (C), Combined artemisinin and NAC constant dose therapy group (D), and Combined artemisinin and NAC tapering dose therapy group (E).

Parasite. P. berghei ANKA strain from Laboratory of Parasitology, Medical Faculty Gajah Mada University was used. Before inoculation, P. berghei was thawed from liquid nitrogen and washed with RPMI in the laminary flow. Inoculation was done by intraperitoneal (i.p) injection of $10^{6}$ parasite in $0.2 \mathrm{~mL}$ blood/mice.

Previously, the number of erythrocytes per $\mathrm{mL}$ of blood and parasitemia of mice donor were counted. Blood from the tails were taken $\pm 10 \mu \mathrm{L}$ and diluted $10^{4}$ in RPMI. The number of erythrocytes were counted in erythrocytes Naubauer, using the formula $\mathrm{N}$ x $5 \mathrm{x}$ $10^{4} \mathrm{x}$ dilution, $\mathrm{N}$ is the number of erythrocytes. The number of parasites from mice donor was counted by multiplying the number of erythrocytes per $\mathrm{mL}$ of blood and the percentage of parasitemia. After $P$. berghei was transferred to mice, every two days parasitemia was checked. Approximately six days post infection, or when parasitemia reached $\pm 10 \%$ therapy was begun.

Parasitemia. Parasitemia was determined microscopically from blood smear by counting the percentage of infected erythrocytes from 1000 erythrocytes at 1000X magnification. The blood smear was stained with Giemsa Fluka Giemsa in buffer 1: 9 proportion. Giemsa staining was conducted for 20 minutes.

Administration of Artemisinin and $\mathrm{N}$-Acetyl Cysteine (NAC). Artemisinin was given to mice orally 0.04 $\mathrm{mg} / \mathrm{g} \mathrm{BW} /$ daily for 7 days. Constant dose of NAC 1 $\mathrm{mg} / \mathrm{g} \mathrm{BW} /$ daily was given to mice orally for 7 days and tapering dose given to mice were $1 \mathrm{mg} / \mathrm{g}$ BW for 3 days continued with $0.5 \mathrm{mg} / \mathrm{g}$ BM per oral for 4 days.

Measurement of IL-12p70. Blood samples from mice collected from the heart were taken into BD Vacutainer Lithium Heparin (BD Franklin Lakes NJ USA, REF 367884). Plasma was separated from blood samples by centrifugation in $4^{\circ}$ Celcius at 3000 RPM for 5 minutes. Plasma IL-12p70 level was determined by quantitative sandwich enzyme-linked immunosorbent assay (ELISA; Bender Medsystems GmbH, Vienna, cat. BMS6004) following the manufacturer's procedure. The sensitivity of detection for cytokine was $<10 \mathrm{pg} / \mathrm{ml}$.

Statistical Analysis. Comparisons across multiple groups were performed by ANOVA one way, and when differences were significant, pair-wise comparisons between conditions were performed by Tukey. Pearson correlation analysis was used to know the correlation between parasitemia and plasma IL-12p70 levels. Determination of significance was at $\alpha=0.05$.

\section{RESULTS}

\section{Parasitemia}

All of the mice were treated at the time when parasitemia reached $\pm 10 \%$. As shown in Figure 1.

\section{The Degree of Parasitemia}

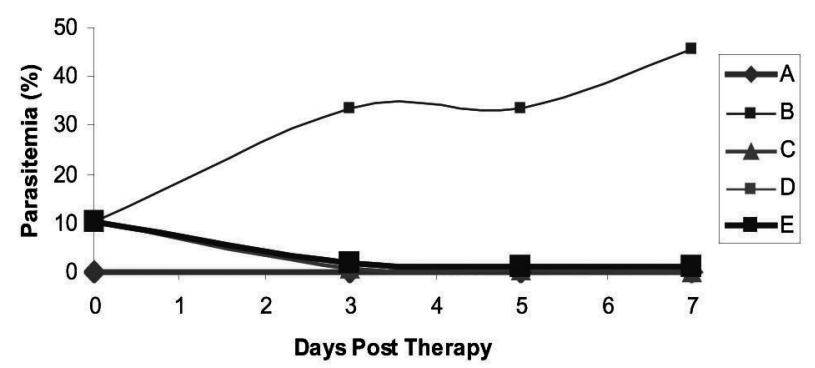

Figure 1. Parasitemia in mice infected with P. berghei and treated with combined artemisinin and NAC.

Normal mice group (A), non therapy of infected mice group (B) artemisinin therapy group $(C)$ artemisinin plus NAC constant dose therapy group (D), and artemisinin plus NAC tapering dose therapy group (E). Parasitemia was observed on the 0, $3^{\text {th }}, 5^{\text {th }}$, and $7^{\text {th }}$ day post therapy.

The degree of parasitemia in mice that were given artemisinin mono therapy and combined therapy were significantly decreased $(\mathrm{P}=0.000)$. There was no significant difference $(\mathrm{P}>0.05)$ of decreasing parasitemia among artemisinin mono therapy group $(\mathrm{C})$, combination of artemisinin and NAC in constant dose therapy group (D), and combination of artemisinin and NAC tapering dose therapy group (E). The percentage of parasitemia among those groups on the $0,3^{\text {rd }}, 5^{\text {th }}$, and $7^{\text {th }}$ days post therapy were not significantly different $(\mathrm{P}>0.05)$. The highest parasitemia was observed in the non-therapy infected group (B) on the $7^{\text {th }}$ day $(45.47 \%)$ and the lowest parasitemia in the artemisinin therapy group $(\mathrm{C}), 0.17 \%$.

\section{Plasma Interleukin-12p70 (IL-12p70) Level}

Plasma Interleukin-12p70 (IL-12p70) level in the normal mice group (A) was $1021.810 \mathrm{pg} / \mathrm{mL}$. Infection of $P$. berghei caused an alteration of the plasma IL-12p70 level. As shown in Figure 2, plasma IL-12p70 level in all mice infected with $P$. berghei decreased $(277.048 \mathrm{pg} / \mathrm{mL})$ day 
0 and increased on the $3^{\text {rd }}$ day post therapy. There were no significant difference among all groups on the $3^{\text {th }}$ day post therapy. Plasma IL-12p70 level in the combination of artemisinin and NAC tapering dose therapy group (E) was higher than that in other groups on the $5^{\text {th }}$ and $7^{\text {th }}$ days post therapy. The highest plasma IL-12p70 level from all mice was found in the combination of artemisinin and NAC tapering dose therapy group (E) on the $7^{\text {th }}$ day post therapy $(1432.286 \mathrm{pg} / \mathrm{mL})$. The plasma IL-12p70 level of artemisinin and NAC tapering dose therapy group (E) on the $7^{\text {th }}$ day post therapy was significantly different $(\mathrm{P}<0.05)$ with that in normal mice group $(\mathrm{A})$, non-therapy of mice infected (B) on the $3^{\text {th }}, 5^{\text {th }}$ and $7^{\text {th }}$ days post therapy, artemisinin therapy group (C) on the $3^{\text {th }} 5^{\text {th }}$ and $7^{\text {th }}$ days post therapy and combination of artemisinin and NAC constant dose therapy group (D) on the $3^{\text {th }}$ and $5^{\text {th }}$ days post therapy. The plasma IL12 p70 level showed a weak inverse correlations with parasitemia $(r=-140)$.

\section{Plasma IL-12p70 Level}

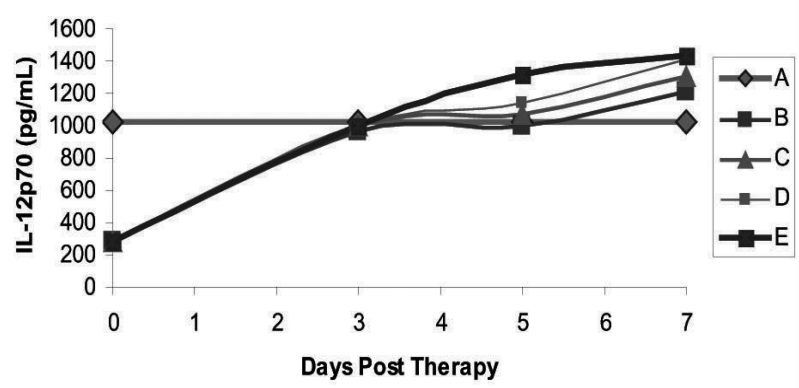

Figure 2. IL-12p70 Plasma level in mice infected with P. berghei and treated with combined artemisinin and NAC.

Normal mice group (A), non therapy of infected mice group (B) artemisinin therapy group $(C)$ artemisinin plus NAC constant dose therapy group (D), and artemisinin plus NAC tapering dose therapy group (E). Level of plasma IL-12p70 was measured on the $0,3^{\text {th }}, 5^{\text {th }}$, and $7^{\text {th }}$ day post therapy.

\section{DISCUSSIONS}

$\mathrm{N}$-acetyl-cysteine (NAC) is an acetylated cysteine residue. NAC is deacetylated to yield L-cysteine in cells. NAC can promote intracellular gluthatione (GSH) synthesis, ${ }^{13}$ while GSH promoted IL-12 production by antigen presenting cells. This could trigger a differentiation of the immune response to the pathway of type 1 T helper. ${ }^{9}$ Using NAC without an antimalaria was investigated in mice infected with $P$. berghei, but single therapy of NAC had no effect in decreasing parasitemia, it was proposed that NAC acts as cytostatic. ${ }^{8}$ Therefore, this research used NAC with an antimalaria, artemisinin. Artemisinin was recommended in combination with other antimalaria or supportive drugs to avoid resistance. ${ }^{2}$ Artemisinin derivatives act as blood schizontocidal agents that effectively inhibit parasites growth. ${ }^{14}$

All mice groups that were given artemisinin showed decreasing parasitemia, but inactive parasites were still found in the erythrocytes, in the crisis form and the degenerate form. Decreasing parasitemia in therapy groups was observed on the third day until the seventh day post therapy. This evidence revealed that artemisinin is an effective antimalaria. This research found that there was no significant difference in decreasing parasitemia between artemisinin mono therapy group and combination of artemisinin and NAC therapy group, because NAC does not kill parasites directly but acts as cytostatic to inhibit the growth of parasites. ${ }^{8}$

In malaria infection, type 1 immune responses control the parasitemia, while type 2 immune responses prevent enhanced pathology through attenuation of proinflammatory cytokine production for successful resolution of malaria. ${ }^{16}$ IL-12 is associated with severity of disease in children with hyperparasitemia. ${ }^{17}$ IL-12 polarizes the inflammation towards the pathway of type 1 immune response. ${ }^{18}$ Ingestion of hemozoin by monocytes promotes the overproduction of IL10 and TNF- $\alpha$ related to low production of IL-12, which correlates with an enhanced severity of mild malaria, showing the inverse correlation of IL-12 with parasitemia. $^{5}$

Interleukin-12 (IL-12) is a disulfide-linked heterodimeric cytokine, composed of two subunits, 40-kDa (p40) and $35-\mathrm{kDa}(\mathrm{p} 35)$ subunits. The two subunits form the $70-$ to $75-\mathrm{kDa}(\mathrm{p} 70)$ protein, which is the biologically active form of IL-12. The results of this research showed that $10 \%$ parasitemia decreased the IL-12 level. It agrees with another study that showed that the infection of $P$. falciparum causes low IL-12 activity. ${ }^{5}$ Hemozoin suppresses IL-12 by augmenting IL-10 and TNF- $\alpha .{ }^{7} \mathrm{NAC}$ is a precursor of glutathione. The production of IL-12 by antigen presenting cells was influenced by glutathione. ${ }^{9}$ So, NAC increases IL-12 level in malaria infection. Plasma IL-12 level in the combination of artemisinin and NAC therapy groups (constant and tapering dose) were significantly higher than that in artemisinin mono-therapy group. However, this research found that plasma IL-12 level has a weak inverse correlations with parasitemia. Plasma IL-12 level in mice that were given combined artemisinin 
and NAC therapy was higher than that in mice that were given artemisinin mono-therapy. Mice treated with artemisinin and NAC tapering dose had the highest plasma IL-12 level. However, it was not significantly different with the plasma IL-12 level of artemisinin and NAC constant dose mice. This revealed that artemisinin and NAC therapy influenced the level of IL-12 in the animal model of malaria.

\section{CONCLUSION}

The conclusion of this research is that artemisinin mono-therapy effectively decreased parasitemia as well as combination therapy consisting of artemisinin and NAC. Artemisinin and NAC combination therapy, constant and tapering dose, increase plasma IL-12p70 level more than artemisinin mono therapy does. The highest plasma IL-12p70 level was found in the combination of artemisinin and NAC tapering dose therapy group with a duration of seven days. For further research we suggest the evaluation of IL-12 and other cytokines as means for monitoring the success of therapy and the elimination of the pathology of malaria infection.

\section{Acknowledgment}

To the Ministry of Research and Technology of Indonesia who gave funding for this research.

\section{REFERENCES}

1. World Health Organization 2005. World Malaria Report 2005. United Nations Children's Fund, World Health Organization, Geneva, Switzerland. http://www. rollbackmalaria.org/wmr2005/pdf/WMReport_lr.pdf

2. Tjitra E. Pengobatan malaria dengan kombinasi artemisinin. Presented on National Symposium of Malarial Eradication, Surabaya, 29-30 November 2004.

3. NCBI, 2000. Plasmodium berghei. (http://www.ncbi.nlm. nih.gov/projects/Malaria/Rodent/berghei.html), accessed 5 August, 2007.

4. Abbas AK, \& Lichtman AH. Cellular and Molecular Immunology. Fifth Edition. Elseveier Saunders, Philadelphia, 2005.

5. Luty, Adrian JF, Perkins, Douglas J, LeLi B, Schmid-ott $\mathrm{R}$, Lehman LG et al. Low interleukin-12 activity in severe
Plasmodium falciparum malaria. Infection and Immunity, 2000; 68 (7):3909-15.

6. Sam H, Stevenson MM. In Vivo IL-12 Production and IL-12 Receptors b1 and b2 mRNA Expression in the Spleen Are Differentially Up-Regulated in Resistant B6 and Susceptible A/J Mice During Early BloodStage Plasmodium chabaudi AS Malaria, The Journal of Immunology, 1999; 162:1582-9.

7. Keller, Christopher C, Yamo O, Ouma C, Ong'echa JM, Ounah D et al. Acquisition of hemozoin by monocytes down-regulates interleukin-12p40 (IL-12p40) transcripts and circulating IL-12p70 through an IL-10-dependent mechanism: in vivo and in vitro findings in severe malarial anemia. Infection and Immunity, 2006; 74 (9):5249-60.

8. Iskandar A. Efek Sinergis Chloroquine dan N-Acetyl Cysteine terhadap Penurunan Aktivitas Radikal Babas Eritrosit dan Peningkatan Aktivitas Fagositosis Makrofag Peritoneal Mencit BALB/c yang Diinfeksi Plasmodium berghei. Tesis Unpublished: Program Pasca Sarjana Universitas Brawijaya Malang, 2005.

9. Peterson JD, Herzenberg LA, Vasquez K, Waltenbaugh C. Glutathione levels in antigen-presenting cells modulate Th1 versus Th2 response patterns. Proc Natl Acad Sci USA, 1998; 95:3071-6.

10. Khan, Nooruddin, Rahim, Sheikh Showkat, Boddupalli et al. Hydrogen peroxide inhibits IL-12 p40 induction in macrophages by inhibiting c-rel translocation to the nucleus through activation of calmodulin protein. Blood. 2006; 107 (4):1513-20.

11. Treeprasertsuk S, Kruudsood S, Tosukl OT. N-Acetyl Cysteine in Severe falciparum in Thailand, Southeast Asian. J Trop/Med Public Health (Abstract). 2003; 34: 37-42.

12. Watt G, Jongsakul K, Ruangvirayuth R. A pilot study of $\mathrm{N}$-acetylcysteine as adjunctive therapy for severe malaria, Q J Med. 2002; 95: 285-90.

13. Flora SD, Izzoti A, D'agostini, F. Balansky RM. Mechanism of $\mathrm{N}$-acetylcysteine in the preventation of DNA damage and cancer, with special reference to smoking-related andpoints. Carcinogenesis, 2001; 22 (7):990-1013.

14. Boxtel CJV. Artemisia and artemisinin, a story about toxicity Uppsala Reports 25 - April 2004 Supplement

15. Ridley, Robert G. Malaria: To kill a parasite, Nature 2003;424:887-889.

16. Stevenson MM, EM Riley. Innate immunity to malaria. Nat Rev Immunol. 2004;4:169-180.

17. Perkins DJ, JB Weinberg, PG Kremsner. Reduced interleukin12 and transforming growth factor-betal in severe childhood malaria: relationship of cytokine balance with disease severity. J Infect Dis. 2000; 182:988-92.

18. Abbas AK, Lichtman AH, Pillai, S. Cellular and Molecular Immunology. Sixth Edition. Elseveier Saunders, Philadelphia, 2007. 